\title{
Perception of nursing faculty on the care: Heidegger constructions
}

\author{
Percepção de docentes de enfermagem sobre o cuidado: uma construção heideggeriana \\ Percepción de la facultad de enfermería en el cuidado: la construcción Heidegger
}

Luciara Fabiane Sebold', Silvana Silveira Kempfer², Juliana Balbinot Reis Girondi³, Marta Lenise Prado ${ }^{4}$

1,2,3,4 Universidade Federal de Santa Catariana. Florianópolis-SC, Brazil.

\begin{abstract}
Objective: To understand the perceptions of nursing teachers about care in the light of Heidegger's framework. It was used as theoretical and methodological reference Heidegger's hermeneutics. Method: To capture the meanings we used phenomenological interviews with 11 teachers. The data analysis is based on heideggerian hermeneutic. Results: The way to be a nurse determines their way of life to the care that reflects the construction of experiences in the nursing worldliness. The existence of the nurse for nursing care is evidenced in care relations established between being careful and being caregiver, deciding the mode of being-there of the nurse who has before him and on the other the possibilities of care. Conclusion: It is being in the world that the being-nurse is manifested in their subjectivity in care for sensitive, is the objectivity of scientific care, and is in the interrelationship with being careful is that manifests the being of choices and existing decisions in his way of being.
\end{abstract}

\section{DESCRIPTORS}

Nursing; Nursing Care;Nursing Teachers; Teaching. 


\section{INTRODUCTION}

In the existential point of view, care, one of the forms of preservation of life, is implicit in the human being's relationships of existence. Care can be understood as an act, when it occupies an ontic meaning, and as a meaning that goes beyond the act, when it concerns itself with the human being, assuming the ontological meaning.

The care as presented to us by Heidegger indicates the possibility of the human being, or 'being-there' (Dasein) in the world. The being-with existentially constitutes the 'being-in-the-world', and should be interpreted by the phenomenon of the cure, because this determines the being of the presence in general. The 'being-in-the-world' is cure, it is care, in both occupation and in concern, even if in a primitive manner ${ }^{(1)}$.

Care belongs to the possibility of the can-be-in-full, as a possibility of its $c a n-b e$ in general. This peculiarity derives from the fact that the 'being there' has the character of having been launched into the world. Care determines what is as it is in the world, and that this world is shared, because the Dasein is always a being-with, an entity that lives and lives together with other Daseins, in the sense that existentiality, facticity and decadence, because they are ways of being, are also ethical/moral modes of the human being existing in the world ${ }^{(2)}$.

'Care' derives from the Latin cura, used in a context of relationships of love and friendship, in a demonstration of concern and of disquietude for the person loved or for an object of esteem ${ }^{(3)}$.

One of the fundamental tasks of the human condition is the act of caring which is consolidated through the link between the carer and the person being cared for, as an attitude of humanity. Care, then, becomes the fundamental identification for Nursing, which over time defines itself and affirms itself as a profession, developing a corpus of knowledge of its own, legitimizing itself as an epistemological object, within the various social and political contexts. Through these, the teaching institutions and the professionals of the practice develop and improve nursing care, considering it as the very essence of the professional itself. This domain of knowledge confers upon them the competency of caring for human beings, in all the dimensions of their process of living ${ }^{(4)}$.

In this respect, care is related to the very existence, or mode-of-being, of nurses. It is through care that they reveal themselves in the different realities of activity, functions and responsibilities.

Care has been defined through principles and concepts, which at the same time range over epistemology, the quality of being scientific, and philosophy; and in these principles and concepts, permeated by ethics, it assumes a new perspective of care-for-health ${ }^{(5)}$.

The professional nurse finds him/herself before the transformations of the modern world and must think critically, have competencies with ethical commitments and commitments in terms of citizenship, autonomy, the capacity to resolve problems, and to reflect and transform his/ her practice, because technical abilities alone do not supply the present needs of the human being ${ }^{(6)}$.

Care can reveal the modes-of-being of each nurse, especially those who have chosen teaching to show themselves in the world of possibilities of teaching. Thus the modes-of-being for teaching of care are built over time by their experiences in the world and, in this respect, the 'being-there' (Dasein) is capable of making its choices and deciding its path, and, faced with situations, seeing and visualizing possibilities when being, and when being launched in the world. 'Being-there' manifests itself, unveils itself before the world, and these characteristics are ontological or existential ${ }^{(1)}$.

The objective of this text is to comprehend the perception of teachers of nursing about care in the light of Heidegger's frame of reference.

\section{METHODOLOGY}

This is a qualitative, phenomenological approach within the framework of Heidegger, developed in a Federal Higher Educational Institution (IFES) of the South of Brazil. Eleven nursing teachers took part in the study. The criterion for inclusion was that the participants should be employed in the Nursing Department. Criteria for exclusion were: Teachers with less than one year's work in the department; teachers with a temporary contract; and having been part of the qualification judgement bench of the doctorate project.

Data was collected through a phenomenological interview, which has the character of revealing the phenomenon through free language, through the orienting questions of the survey. A phenomenological interview takes place in the form of an existential meeting ${ }^{(7)}$.In this type of interview the investigator makes use of his/her empathy and inter-subjectivity, leaving the subject who is being interviewed to feel free to conduct his thought and language in whatever way he/she thinks most appropriate.

The interviews were recorded, with prior permission, and took place in the following phases:

Initially, Approach to the interviewed party, establishing a dialog dealing with aspects relating to his/her professional history in nursing; the type of study was explained, and the objective and the way in which the interview would be conducted, it being made clear that there would be no interruption in the interviewee's speeches, so that he/she could develop their free thinking.

The orienting question of the study was then put: "Who are you, a nurse-teacher-being who teaches-learns care?" This was written on a card visible to the interviewee.

The statements were recorded, transcribed, and organized, after which there was an exhaustive reading of the information. The data were codified with the intention of grouping the statements that presented similarity, demonstrating the expressions of the nurse teachers on the perceptions about nursing care, providing input to the subject, and the units of meaning that will be described below. Thus, the data were analyzed based on hermeneutics 
in accordance with Heidegger, and in harmony with the relevant literature.

The hermeneutical circle comprises: Pre-comprehension; Comprehension, and Interpretation; These permeate the whole of the work Being and Time and are developed in more depth in paragraph 32. ${ }^{(1)}$. "The hermeneutics of 'being-there' becomes also a 'hermeneutics' in the sense of elaboration of conditions of possibility of every ontological investigation" - bearing witness to the singularity of human life ${ }^{(1: 77)}$.

Thus, pre-comprehension is considered to be a reporting to the existing, with pre-suppositions, or, in other words, the interpreter makes use of pre-determined positions or a prior position of day-to-day interpretation of what he sees around $\mathrm{him}^{(1)}$. In this study the pre-comprehension includes the knowledge produced and experienced by the investigators.

Comprehension means being connected to an existential reality that is essentially possibilities of being. To understand the existential being is the very can-be itself of presence, so that, in itself, the latter opens and shows how its own being operates ${ }^{(1)}$.

Interpretation is based existentially on understanding: it is the preparing of new possibilities projected in understanding. Interpretation makes its movement in the structure of the pre-comprehension that has already been characterized, that is to say, interpretation is never the apprehension of a given item of data free of pre-suppositions. "All interpretation that places itself in the movement of understanding must already have understood what it is wished to interpret"(1:213). Thus the discussion of the data of this study is characterized in interpretation completing the hermeneutic circle, and immediately opening to new horizons of possible pre-comprehensions and comprehensions of the way of being of the nurse teachers.

The data were collected in the second semester of 2010, after approval of the project by the Research Ethics Committee of the Federal University of Santa Catarina, under Protocol No 996/2010. The ethical aspects of research as put forward in Resolution 466/12 of the National Health Council of the Health Ministry were obeyed. The participating subjects signed the Informed Consent Form. Their anonymity was preserved: They were identified by the letter $\mathrm{D}$ followed by the number of the related interview.

\section{RESULTS}

The results presented refer to comprehension within the terms of reference of the Heidegger Hermeneutical Cycle. Thus, considering the wide and complex concept of care, which involves the objectivity and the subjectivity that permeate the human being in all its complexity of living, it is noted that the findings of this study point to the diversities of the ways of being for care.

The concepts of care constructed from the responses given by the nurse teachers in their experiences of care can be resolved into the following units of meaning: The meaning of Care for the Other; the meaning of Care for Teaching; and the meaning of the Experiences of Care.

\section{The meaning of Care for the Other}

In this unit the nurse teachers emphasize that, for care to be wide-ranging, it is essential that the carer and the person cared for should be close, denoting a care with empathy, in such a way that the carer and his/her subject of care feel at ease to manifest their possibilities of being-with. Thus their view is that, when identifying peoples' needs, they can help them at the moment at which they need care - considering the Other as someone who is close, and the possibility of helping that Other person from the point of view that he/she judges to be important. In this respect, the nurse teachers allowed the following affirmations to flow in their speech:
I think this word "care" is what is really the finest thing in nursing, this concept of someone who takes care. I don't want to go into the etymology of the word, but it's someone who is close: No one can take care with his back turned to you, and no one takes care from a distance - he has to be close (D07)
Care as a conception of the essence of nursing, of care in the sense of being with the other, of having one's atten- tion centered on the other to help that other in whate- ver he or she may need. So care from this perspective, always trying to identify what is important for that person (the patient), how I can help that person so that he/she can better take care of him/herself (D11)

The nurse teachers affirmed that care is amplified to the extent that it transcends technical actions, or limited to actions. It goes beyond doing something for people in the sense of the traditional model. And they amplify it, by this means, to another dimension, which can involve other professionals adding knowledge and improving and perfecting the forms of care.
When we are working on a literacy project for elderly people, which is an area of education, I see it as an area of care also. So I am there as a nurse and teacher, and there is an educator there from the education center - we meet and do a project - I find this very important. Because this is care. And why do I think this is care? Because as from the moment that the el- derly person learns to read better, he can live his old age better (D08)

Care in the sense of a care that goes beyond the physical, the biological. I think that we have always to try to work on a care that serves those people, those individuals who are around us (D05)

The relationship with the world shows the ways in which the nurse teachers think about and execute care. This movement also opens to the possibility of care having to do with people's autonomy. In this response the nurse teacher highlights that care can also be autonomy:
The IT project for the third age. The elderly person can know how to turn the computer on and off, to go to an ATM and how to deal with all this, that is an auto- nomy! The capacity to see the possibility of living this old 
age. In the area that I work most, this is also care, because when you work with elderly people, you have to look to their potentialities, trying to minimize their incapacities. At the moment that you are seeking to minimize their incapacities, giving them new skills, giving value to the skills that they already have and complementing with others, you give the person an arsenal, a set of instruments for him/her to live better (D08)

Dialog as a constitutive part of care is shown in the interviewees' speeches. Care takes place through the dialog between people and, thus, sharing is one of the expressions that consolidate this way of caring.

Conversing with people is also a form of care... I think
that everywhere you can be teaching someone and be
learning. This is the way that I see teaching-learning,
it's the way for you to have dialog, horizontal, sensiti-
ve, it has to have sensitivity, there is no care without
sensitivity, without looking at the other person, wi-
thout sharing something, or having compassion. You
always share something, your knowledge, or just a tou-
ch of the hand-I think that's how it is (D10)

There is the argument that being-in-the-world is: being launched into a universe of possibilities, projecting the being-there to an ability-to-become. That is the meaning that the nurse teachers reveal in their ways-of-being, expanding their horizons through the movement of care $^{(1)}$.

\section{The meaning of Care for Teaching}

For the nurse teachers, occupation with training is also a mode of care, that they show to be related to teaching and learning. The teaching of care starts from a reflection with the pupils, for the purpose of making them sensitive to the importance of committed and responsible, and, consequently, safe, care. Taking the pupil into consideration and stimulating his/her movement as well.

When you're training a professional for care, the responsibility is really enormous. These are lives that you are helping the pupil to take care of, orienting care for lives. Because you are not dealing with material, with paper. It's with a human being! I always say, what I say, when I give a lesson to the pupil, I always put it like this: You must give care in the way that you would like to be taken care of, provide the best care possible, so you have to study, associate theory with practice to be able to give the safest care possible: Responsibility comes first - don't do anything that you don't know how to do - these are lives! (D03)

I see myself as a teacher, today I have this responsibility of teaching to care, and helping to take care of our house, our house, our environment. And this discipline [...] this is what I say to the pupils: We have the responsibility of giving care. And we are taking care, not only of the lives of people, but it seems that there is a deviation of opinion, that we are only taking care of human life, but we are carers for the life of the planet (D07)
Another point that calls attention is care for the pupils, since the nurse teachers perceive that it is a way, also, of teaching care through comprehension and tenderness, and that this way of being a nurse teacher is specific and particular in comparison to other cases.
Although we say "we are primarily teachers", we finish up actually taking care. The other day the pupils called my attention to this, to the fact that they don't find, in the disciplines of other centers, other departments, this way of working that we have in nursing, which is a way of taking care, that's a concern for them, how they are. And that's why we perceive that there is a blending in this: we say that this way of educating, of teaching, learning, and taking care, does not dispense with rigor (another very monk-like word) - that you have a whole relationship of affection, of care for the other person, but you also have the commitment and the responsibility for this learning. (D09)

In this study there is the concern with the care taught and the care learned: The way of being in care can in future reflect on the pupils' day-to-day life in work. This is shown by this statement:
Another thing that frustrates me here in the univer- sity, that I see in the curriculum, is that although there is the center-line of care, it is lost in some contents, in some disciplines, it does not have its own philosophy, it does not have a way of moving forward. In the cour- se of the curriculum it happens at isolated moments, it does not have an automatic, reflex result. And I think that at the end of the course there should be workshops of care, and also at the beginning, entering, just as at the end of the course. As the pupil is leaving, what is the base of care, what paradigm of care is he taking wi- th him out of this course? We see it like this, that some pupils are coming from [...] with a very good humani- $z e d$ basis, one can see it, that they are coming to us di- fferently from how it was in the past, they are coming to us very conscious, with the ethical questions, with respect for the patient, but is it true that this pupil gets to the end of the course still like this? Does this concept and this form of acting remain or not remain? We find former pupils with another profile, so the profile was not properly closed. (D010)

The care taken on training covers aspects of responsibility, orientation and commitment, however without losing the relationship of affection that involves the nurse teacher and his/her pupil.

\section{The meaning of the EXPeriences of CARE}

In this unit of meaning the nurse teachers attribute their ways of being toward care built up in the experience that they have lived through over the course of their professional histories, and believe that this contributes to their formation, to the ways of teaching - and to their understanding that it is by teaching that one learns, also. 
We learn every day, these are the experiences that one has, new contacts that you make and this learning of care is one thing... and also, thus, our pupils, and that they should succeed in seeing this in a wider way I think even that my professional experience has become a little different (D05)

I have a very big background experience in care, and also in management, and I thought I had what was necessary to come to teaching bringing rich experiences for teaching of nursing, and I think that this helps and is important, this helps for working with care. For me this is a value, because I am able to mediate these two spaces, I succeed in looking at the space of assistance and care where I am involved with practical theoretical activity, and also, I succeed in seeing myself there within as a nurse and thinking, planning and helping (DO2)

However, the nurse teachers seek knowledge in other areas and, thus, strengthen the experiences of care for the purpose of better understanding this specificity of being a nurse, as well as observing the importance of studying care itself deeply.
And I think that this field of education, understanding educational theories, the different philosophies, it made possible a greater comprehension for me of the human being. I think that philosophy, sociology, everything about the formation of societies, this whole process very much enriched my practice as a nurse because it made me able to understand a little better. I think this hu- man being that I have before me, who needs care, this subject's quest for autonomy, and all this perspective that finishes up resulting in this meeting and crossing of these areas of knowledge, I think that this learning about care was very important for success in making this joining of various areas of knowledge, and better understanding the importance of care. I think that be- cause of these experiences, because of having succeeded in ceasing to be a simply prescribing nurse to become a nurse that listens to the other person, that builds toge- ther, who is concerned with the patient's sharing of hisl her history of becoming ill and of health (D09)
I like to study care. The other day I was thinking: What more will I like to study and research? I think that today it is still necessary to study and research care. People are going along the outside, researching certain acts, but not going deep - and this would be the real contribution to care. I think that we have to have a very important role for the future, which is training nurses (D10)

The experiences of life constitute an exercise in coming-to-be, because this way of questioning reality and seeking different ways forward constitutes the nurse teacher who is more sensitive to care, because he is integrated into an approach that seeks responses, revealing the propensity of the being-there in relation to the other, in the sense of concern and zeal for one's fellow human being.

\section{DISCUSSION}

The nurse teachers, in this study, show their way-of-being for care, in special and peculiar ways. Through their understanding and their experiences, they conceive their way of being in the world of teaching nursing. In accordance with their ways of being, they determine their horizons in the critical-reflexive exercise of their practices of care. Thus, a human being can only define him/herself based on her existence, her possibility of being or not being what she is in her view around herself. They show the existential meaning of the presence where care is occupation and concern $^{(8)}$.

However, the nurse teacher also at the same time moves in the world of care and of teaching, revealing his/her versatility in expressing that care is proximate, expands meanings, promotes autonomy, and is based on dialog. It is understood as the possibility of being situated in circumstances of its world and to the constant exercise of existing in it, while the nurse teachers understand their world, their purposes and the purposes of the others with whom they live. It is to be launched into the game of life, itself, which through its experiences lived, opens into a horizon of possibilities, being able to choose and decide the paths it takes, which means assuming responsibilities to the present and to the future of teaching of nursing care ${ }^{(9)}$.

The becoming-with-the-other can be signaled when the care is perceived as a possibility of proximity to, or being-with the other, and this exposes the fact that care cannot be carried out without presence, that is to say, in the mode of being-there in the relationships with the world determining its day-to-day practice. The way of being with others breaks the fragmentation of care, favoring a better and healthier life, and people's integration around the good as a social, political, ethical and cultural link is a fundamental condition $^{(10)}$.

Care based on dialog establishes relationships which open possibilities for other dimensions that strengthen the being and the doing of nursing, demonstrating that the relationships constituted by attention and concern with the other are fundamental, revealing the meaning of being in the existence, itself, of the profession. The relationships established in care are present in the knowing-doing of nursing. Relationships of affection are an important part of the daily life of the teachers' teaching and constitute the imaginary area of the pupils who, when coming face-to-face with care for people, feel that situations that they have lived through in the histories of their personal lives are emerging $^{(11)}$. Thus, dialog is an existential mode of being-in-the-world of the nurse teachers who seek, through it, to take care of the other.

This being so, Care for one's fellow man is presence. It is the opening to the possibility of being and being-with-the-other, characterizing the occupation of the world and concern with the other, and, temporarily, assuming responsibility for the other. Through proximity dialog becomes possible, identifying the other's need, which means finding the other important, being and staying in the presence of 
the other, sharing knowledge and assuming the presence as a possibility of liberty for being able to be closer.

The concern for the other is also a way of being for the person cared for. As a result of this, the nurse teachers explain that teaching is integrated with the relationships established with the pupil, who is in the world of teaching-learning, because they understand that this way they can, as well as caring, teach through the experience of living together itself. The being-in-the-world is always cared for to the extent that it relates to the other beings, and points out that concern is also an occupation with others, and that, in day-to-day life, these are veiled in social relations, resulting in the condition of human joint living sometimes getting closer to and sometimes being further from those who live with us ${ }^{(1)}$.

Care is a form of ownership of the way-of-being in the world, a way of being one's self at each new instant; evidencing that in the being-there nothing is as it is, but that everything in it is a project of being-able-to-be, that is to say, the nurses' ways of being ennoble the ways-of-being for care. This perspective implies that care is not only occupation, in the sense of a use of things in daily life and of the most varied possible tasks in relation to those things; nor is it concern, but indicates behavior with the other or, yet, to the other ${ }^{(12)}$.

There is a possibility of thinking that the nurse teacher is a professional who among other qualities is also sensitive to a differentiated care, that can make the difference in the world of teaching of nursing. In this aspect he/she is the being living her possibilities in a world shared with others, demonstrating their concerns, characterizing their way of being for care: showing herself to be interested in the health, the wellbeing and the life of the other, whether healthy or infirm, and concerning, respecting, understanding and taking responsibility for the care ${ }^{(13)}$. The constant reflection of the exercise of care strengthens a nursing that is humanistic, where the concern and the zeal for people who will be taken care of becomes irreplaceable.

As a function of this, it becomes necessary that the nurse teachers should exercise the reflection of teaching-learning care, basing what they do on a pedagogy which gives a primary position to criticality and creativity in teaching. For this challenge, it is vital that the teaching of nursing should assume a reflection that sustains a significant learning, which is transformative, which considers the learner individually with his/her potentials and difficulties, directing attention to transformation and not to uncritical reproduction of the social reality ${ }^{(14)}$. As a consequence of this, nurse teachers who make care their way-of-being can reflect on the true function of teaching. The "specific function of the teacher is to care for the pupil's learning, with concentration and energy, dedication, a systematic approach, continuity and persistence"(15:24).

Care for teaching is the way-of-being in the presence with commitment to the other, to whom one teaches and of whom one takes care, making choices and taking decisions, with responsibility for teaching - it is the possible ways of being in the manner of occupying one's self and concerning one's self with the other, understanding the other, maintaining rigor in orientating the other in what he-she has most specific to herself, her essence, creating a situation of harmony to make the being become what it is.

In counterpart, the ways of being of the nurse teacher who teaches-learns care are based on professional experiences, where the quest for knowledge strengthens the presence of the nurse teacher in his overall view of care. This being so, the knowledge that is acquired through the experience can be an important factor for the teaching of care $^{(16)}$.

The nurse teachers participating in this study emphasize that taught care is not the same as is carried out in the day-to-day work of nursing, since the diversity and the manner of teaching it can reflect in a professional without consolidated bases. And, in this sense, the formation and the practice of the nurse need to have experience between the processes of work in the dimensions of carer, management, educator and scientific investigation, harmonized in the historical and social context ${ }^{(14)}$.

At the same time, this diversity can be a differential in the formation of future nurses, having in mind the potential for becoming a professional who reflects and who seeks the possibilities for care in the best way possible. It is understood that care is the meaning and the significance of the human being's existing. It is through this that man makes his presence and comes to exist in relation to the other and the world. It is highlighted, also, that care, even before being and being realized as an action, expresses a way of being, of feeling and of living, and is intrinsically related to the essence of man's being ${ }^{(17)}$.

This human being lives in a world constituted by man's relationships with things and with other men. Thus, the world is part of his being, that is to say, being in the world of life is to be part of it, finding oneself faced with challenges and choosing one's path in the face of the existential possibilities.

The care of the being-there is a dynamic that reunites with itself in the face of the comprehension of a certain incompleteness, and of the imminent need to launch oneself toward one's realization at each instant of existence, which leads one to think critically in the face of the innumerable possibilities of care presented in one's world ${ }^{(18)}$.

In this sense, Care in professional and life experiences allied to the quest for knowledge describes the historicity of the being. This being is launched upon the conditions of being-there projecting itself toward its own capacity to become, assuming the responsibility for its choices, which have brought it changes, or personal and professional growth, expanding the possibilities of power-to-be for care.

\section{CONCLUSION}

The nurse teachers in this study perceive care as something empathic; important in the formation of future professionals; and that the construction of the understanding of care has been established through the experiences lived through over the length of their life histories, linked to the knowledge sought in this interim. Having their own cha- 
racteristics, they understand care in accordance with their ways-of-being, perceived through changes in daily life, constructed over time, making possible the opening of horizons to the teaching of care, emphasizing that the wealth of the diversity of experiencing care contributes to the formation of future nursing professionals, and understanding, in this way, that care is characteristic of the nurse-being.

The diversity of the ways-of-being of the nurse teacher brings us to think that this plurality enriches the knowledge and strengthens the base of nursing - that is to say, care - thus making it possible for future professionals to culti- vate the exercise of reflexive criticism, projecting onto their horizons the ways that they will choose for caring. In this aspect, we can explain that the nurse teacher, in relation to care, perceives him/herself in the exercise of being open to possibilities, creating in his/her world the very meaning for care, reflecting and questioning his/her actions, and, thus, revealing his/her own existence.

This study has sought to assist in the development of nurse teachers in their coming-to-be for care in nursing, and to help enable their ways-of-being to be a differential in the training of new care professionals.

\section{RESUMO}

Objetivo: compreender as percepções dos docentes de enfermagem sobre o cuidado à luz do referencial de Heidegger. Utilizou-se como referencial teórico-metodológico hermenêutica heideggeriana. Método: Para captar os significados utilizou-se entrevista fenomenológica realizada com 11 docentes. A análise dos dados baseou-se na hermenêutica heideggeriana. Resultados: $\mathrm{O}$ modo de ser enfermeiro determina seu modo de ser para o cuidado, que é reflexo da construção das experiências na mundaneidade da enfermagem. A existência do ser enfermeiro para o cuidado de enfermagem é evidenciado nas relações de cuidado estabelecidas entre o ser cuidado e o ser cuidador, decidindo o modo de ser-aí do enfermeiro que tem diante de si e do outro as possibilidades de cuidado. Conclusão: É ser-no-mundo que o ser-enfermeiro se manifesta, em sua subjetividade no cuidar sensível, é na objetividade do cuidar científico, e é na inter-relação com o ser cuidado é que manifesta o ser de escolhas e decisões existindo em seu modo de ser.

\section{DESCRITORES}

Enfermagem; Cuidados de Enfermagem; Docentes de Enfermagem; Ensino.

\section{RESUMEN}

Objetivo: Comprender las percepciones de los docentes de enfermería sobre la atención a la luz del marco de Heidegger. Fue utilizado como hermenéutica referente teórico y metodológico de Heidegger. Método: Para capturar los significados que utilizamos entrevistas fenomenológicas con 11 profesores. El análisis de datos se basa en la hermenéutica heideggeriana. Resultados: La manera de ser enfermera determina su modo de vida al cuidado que refleja la construcción de experiencias en la mundanidad de enfermería. La existencia de la enfermera para el cuidado de enfermería se evidencia en las relaciones que se establecen entre el cuidado de cuidado y ser cuidador, de decidir el modo de ser-ahí de la enfermera que tiene delante de él y por el otro las posibilidades de atención. Conclusión: Es estar en el mundo que el ser-enfermera se manifiesta en su subjetividad en el cuidado para pieles sensibles, es la objetividad de la atención científica, y está en la interrelación con cuidado es que se manifiesta el ser de las elecciones y decisiones existentes en su forma de ser.

\section{DESCRIPTORES}

Enfermería; Cuidados de Enfermería; Docentes de Enfermería; Enseñanza.

\section{REFERÊNCIAS}

1. Heidegger M. Ser e tempo. $3^{\text {a }}$ ed. Petrópolis (RJ): Vozes; 2008.

2. Bilibio, E. Os momentos constitutivos do cuidado e o dasein como ser de relações. Rev. ethic@.2013 Dez; 12(2): 272-288.

3. Boff, L. Saber cuidar: ética do humano - compaixão pela terra. 11ª ed. Petrópolis(RJ): Vozes, 2004.

4. Pires Denise. A enfermagem enquanto disciplina, profissão e trabalho. Rev. bras. enferm. [Internet]. 2009 Oct [acesso 2015 Nov 04$]$; $62(5)$ : 739-744. Disponível em: http://www.scielo.br/scielo.php?script=sci_arttext\&pid=S0034-71672009000500015\&lng=en.

5. Carvalho, V. For an epistemology of nursing care and the educational development of the subjects of knowledge in nursing area - a philosophical point of view. Escola Esc Anna Nery Rev Enferm 2009 abr-jun; 13 (2): 406-14

6. Rodrigues, J.; Mantovani, M.F. The nursing professor and their representation about the professional formation. Esc Anna Nery R Enferm 2007 set; 11 (3): $494-9$.

7. Padoin Stela Maris de Mello, Terra Marlene Gomes, Souza Ívis Emília de Oliveira. Life-world of woman with HIV/AIDS in the daily life of the (im)possibility of breastfeeding. Esc. Anna Nery [Internet]. 2011 Mar [cited 2015 Nov 04]; 15( 1): 13-21. Available from: http://www.scielo. br/scielo.php?script=sci_arttext\&pid=S1414-81452011000100003\&lng=en.

8. Waldow Vera Regina. Atualizaçáo do cuidar. Aquichán [periódico na Internet]. 2008 Abr [citado 2015 Nov 04] ; 8( 1): 85-96. Disponível em: http://www.scielo.org.co/scielo.php?script=sci_arttext\&pid=S1657-59972008000100008\&lng=pt.

9. Sebold Luciara Fabiane, Carraro Telma Elisa. The authenticity of the being nursing-professor in the nursing care teaching practice: a Heideggerian hermeneutics Texto contexto - enferm. [Internet]. 2013 Mar [citado 2015 Out 29] ; 22( 1 ): 22-28. Disponível em: http://www.scielo.br/scielo. php?script=sci_arttext\&pid=S0104-07072013000100003\&lng=pt. http://dx.doi.org/10.1590/S0104-07072013000100003.

10. Silva Ide J1, de Oliveira MF, da Silva SE, Polaro SH, Radünz V, dos Santos EK, de Santana ME. Care, self-care and caring of yourself: A paradigmatic understanding thought for nursing care. Rev Esc Enferm USP. 2009 Sep;43(3):697-703 
11. Lazzari Daniele Delacanal, Martini Jussara Gue, Busana Juliano de Amorim. Teaching in higher education in nursing: an integrative literature review. Rev. Gaúcha Enferm. [Internet]. 2015 Set [citado 2015 Out 29] ; 36( 3 ): 93-101. Disponível em: http://www.scielo.br/scielo. php?script=sci_arttext\&pid=S1983-14472015000300093\&lng=pt.

12. Kahlmeyer-Mertens, Roberto S. Cuidado, educação e singularidade: idéias para uma filosofia da educação em bases heideggerianas. Rev Princípios. 2008 jul-dez;15(24):209-223.

13. Rivero Digna Escobar, Erdmann Alacoque Lorenzini. The power of loving humane care in nursing. Rev. Latino-Am. Enfermagem [Internet]. 2007 Aug [cited 2015 Nov 04] ; 15( 4 ): 618-625. Available from: http://www.scielo.br/scielo.php?script=sci_arttext\&pid=S0104$11692007000400015 \& \operatorname{lng}=$ en.

14. Resck Zélia Marilda Rodrigues, Gomes Elizabeth Laus Ribas. Background and managerial practice of nurses: paths for transforming praxis. Rev. Latino-Am. Enfermagem [Internet]. 2008 Feb [cited 2015 Nov 04] ; 16( 1): 71-77. Available from: http://www.scielo.br/scielo.php?script=sci_ arttext\&pid=S0104-11692008000100012\&lng=en.

15. Demo, Pedro. Ser professor é cuidar que o aluno aprenda. 6a ed. Porto Alegre (RS): Meditação, 2009.

16. Joellen, Datillo; Kathleen, Brewer M.; Sterit, Linda. Voices of Experience: Reflections of Nurse Educators. J Contin Educ Nurs. 2009 Aug; 40(8):367-70.

17. Schaurich, Diego; Crossetti, Maria da Graça Oliveira. The dialogical element in nursing care: an attempt based on Martin Buber. Esc Anna Nery Rev Enferm 2008 set; 12 (3): 544-48.

18. Carraro TE, Kempfer SS, Sebold LF, Oliveira MFV, Zeferino MT, Ramos DJS, Frello AT. Cuidado de Saúde: uma aproximação teórico-filosófica com a fenomenologia. Cultura de los cuidados Granada Espanha. 2011; 29: 89-96. 